\title{
Coerced Birth Control, Individual Rights, and Discrimination
}

\section{Lenore Кио}

[Judge Howard Broadman] gave [Darlene Johnson] prison time for whipping two of her four children with a belt and a cord. Then, having just heard of Norplant ${ }^{\otimes}$, the new longlasting contraceptive, he casually decreed that she have it implanted in her arm or else serve more time. When critics protested that Ms. Johnson had medical conditions that might make Norplant ${ }^{\otimes}$ harmful to her, the judge left it up to some doctors to decide whether the device would be safe. ${ }^{1}$

In the past year, a Kansas State legislator has introduced two bills aimed at using Norplant ${ }^{\circledR}$ to control pregnancies ... The first measure ... proposed giving women on welfare $\$ 500$ to have Norplant ${ }^{\circledR}$ inserted and $\$ 50$ for each year it remained in place ... The second proposal ... would make insertion of Norplant ${ }^{\circledR}$ an acceptable condition of probation for women convicted of certain drug offenses. ${ }^{2}$

In January of 1991 , the Norplant ${ }^{\circledR}$ system was introduced into the US. Norplant ${ }^{\circledR}$ is a flexible implant of six tubes containing a 
hormone used in many birth control pills. These tubes are implanted below the skin on the inside of the upper arm of a woman (through a 2-mm incision). Once implanted, the tubes provide a steady level of the hormone, levonorgestel, for as much as 5 years. Current studies indicate that it has a cumulative success rate of $99.4 \%$ in preventing pregnancy, making it "the most effective reversible method of contraception available."

The manner in which Norplant ${ }^{\circledR}$ functions as well as its success rate in preventing pregnancy makes it the first birth control device that can effectively be used coercively “... because it's so long lasting and doesn't require any cooperation after it's implanted, and can be monitored by a parole officer [or other governmental official] just by looking at the woman's arm." It may, at first, appear peculiar to consider specifics of the technology of Norplant ${ }^{\circledR}$ in answering the apparently theoretical question of the justification of coerced birth control. I will argue, however, that issues specific to the development and functioning of birth control technology are central to understanding an adequate answer to the more general theoretical question of the ethical justifiability of coerced birth control.

The scope of this discussion will be limited to the issue of whether or not birth control, a temporary prevention of the capacity to reproduce, may ever be justified. I shall not here be directly concerned with the question of whether or not coercing sterilization, the permanent destruction of a capacity to reproduce, is ever justified. Many of the issues relevant to coerced sterilization are different from those relevant to coerced birth control and further, historically, both ethical doctrine and legal precedent have tended to judge coerced sterilization as unjustifiable. ${ }^{5}$

It is in part because of this perceived difference between sterilization and birth control that the issue of coerced birth control is only now becoming a source of significant controversy. Prior to January 1991, the question of forced birth control was pretty much a purely academic concern. ${ }^{6}$ Although some methods of birth control that existed prior to that time could, in theory, 
have been coerced, any policing of such a practice would have constituted an unacceptable invasion of privacy. The development of Norplant ${ }^{\circledR}$ has made the coercion of birth control practically possible.

\section{Limiting Basic Rights}

Part of the reason coercion to use birth control is such a highly controversial and emotionally charged issue is because such a policy involves limiting four distinct and basic human rights:

1. One's procreative or reproductive right (and/or potentiality);

2. One's right to bodily autonomy;

3. One's right to privacy; and

4. One's right to practice one's religion of choice.

Although no rights are ever absolute, these rights are viewed as fundamental, not only by ethical tradition, but by legal precedent as well. ${ }^{7}$

The US government explicitly acknowledges the right to reproduce, describing it as a "liberty" right, i.e., a right to noninterference so that one "is at liberty to take any action that is not coercing or restraining or designed to injure other persons. ${ }^{8}$ Furthermore, this right is acknowledged to be fundamental to freedom and autonomy.

The right to reproduce appears to be linked to freedom and autonomy in the most basic way: the desire to have children and create a family is a natural expression of generative urges and commitments to religious, ethnic, and familial values that have characterized the human race from its beginning. ${ }^{9}$

The right to bodily autonomy, the right of competent adults to determine what will happen in and to their own bodies, is basic to virtually all ethical systems as well as to all democratic political systems. This right is considered so fundamental that it is regularly used as the basis for deriving other rights, ${ }^{10}$ and is treated 
as virtually absolute by the medical profession. For example, competent adults have regularly been permitted to refuse medical procedures (e.g., blood transfusions), even when death is likely to result without such treatment. A policy of coerced birth control not only limits one's right to bodily autonomy by forcing the individual not to reproduce, it also limits this right by coercing the form of birth control an individual can use. That is, policies of coerced birth control, as evidenced above, are only possible (can only be monitored and policed) if the individual agrees to utilize specific methods of birth control. Therefore, such a policy not only coerces an individual's capacity to reproduce, but also coerces the manner in which this end is to be achieved.

In addition, based on precedent, such a policy would be legally viewed as limiting a basic right to privacy. In Roe v Wade, for example, the court argued that a woman's right to have an abortion (in the first two trimesters of pregnancy) was guaranteed by her right to privacy. ${ }^{11}$ A similar view is held in traditional ethical theory. That is, an individual's right to privacy (including the right to decide the private issue of reproduction) is generally viewed as decisive in the absence of unusual or extenuating circumstances.

Finally, a policy coercing the use of birth control would have to be made conditional on the religious convictions of the individual. Many religious sects severely and explicitly condemn the use of any methods (or of any "unnatural methods"), of birth control. As such, any blanket coercion of birth control would potentially deny religious freedom. Policies can and have been made conditional on the individual's religious convictions. Quakers, for example, have been permitted to do "alternative service" rather than fight during war times. So at least in theory, a policy of coerced birth control could avoid violating one's right to religious freedom if the policy was made appropriately conditional.

Despite how fundamental the rights of reproduction, bodily autonomy, and privacy are, they, like all rights, are never absolute. All rights may be restricted at times. For example, a right is not 
absolute when one's exercise of it violates the rights of another. (My right to free bodily movement, for example, does not include a right to enter your home, since this violates your right to privacy and private property.)

Traditionally, ethicists have argued about what grounds justify limiting an individual's rights and liberties. J. S. Mill held that "the only purpose for which power can be rightfully exercised over any member of a civilized community, against his will, is to prevent harm to others" "where "harm to others" includes both harm to other individuals or harm to society and/or its institutions.

Although many other grounds for limiting individual rights have been considered by traditional ethicists, ${ }^{13}$ no other grounds have historically been viewed, either by most ethicists or by US legal or medical policies, as sufficient to limit the right of a competent adult to bodily autonomy. ${ }^{14}$

In addition, policies restricting basic rights have been held to be justifiable only where the harm is "highly probable or in the case of a very serious harm, reasonably probable." "Thus, for example, we have permitted officials to quarantine areas where bubonic plague was discovered because it is a serious disease with a high probability of transmission through casual contact with infected individuals. ${ }^{16}$ We have not permitted officials to quarantine areas where AIDS was discovered because although AIDS is a serious disease, the probability of transmission through casual contact with infected individuals is extremely low. ${ }^{17}$ Thus we cannot limit rights in order to prevent all possible harm. Common sense alone makes it clear that we would have virtually no rights whatsoever if our rights could be limited whenever there was a possibility (or low probability) of causing harm. (We could not, for example, drive cars since there is always a possibility or low probability of injuring a pedestrian.)

Thus, to summarize what has been said so far, we can maintain that limitation of basic human rights, particularly of the right to bodily autonomy, can be justified only if the following condition is met: Such a limitation is required to prevent harm to others 
that is either highly probable or very serious and reasonably probable (The Harm Principle).

There are two additional conditions generally acknowledged to be required in order to justify limiting basic rights.

First, the manner or method used to limit a right must be rationally related to the harm it is intended to prevent. I cannot limit your right to sing in order to prevent your using drugs (even if it turned out that many people who sing take drugs). This condition is explicitly recognized by ethicists ${ }^{18}$ and by US law. ${ }^{19}$ Thus, for example in Jew Ho v Williamson, the courts held:

If . . a statute purporting to have been enacted to protect the public health, the public morals, or the public safety, has no real or substantial relation to those objects ... it is the duty of the courts to so adjudge, and thereby give effect to the constitution. ${ }^{20}$

Thus in order to justify limiting individual rights, the following condition must be met: Such a limitation must be directly relevant to the prevention of the anticipated harm (The Test of "Rational Relationship").

The third condition, which is also recognized by precedents in ethics and the law, requires that the manner or method used to limit individual freedoms be the least restrictive and least intrusive possible to prevent the anticipated harm. It is, for example, part of the reason for rejecting a policy of quarantining those infected with AIDS since preventing the spread of AIDS can be achieved through far less intrusive means. ${ }^{21}$ It is also part of the basis for the court's decision regarding the forcible administration of drugs in Rennie $\mathrm{v}$ Klein, where it was held that "a patient's constitutional right to be free from treatment may be limited only by the least intrusive infringement required by needed care or legitimate administrative concerns." ${ }^{22}$ Thus we may limit basic rights only if the following condition is met: Such a limitation is justified only ifno less restrictive or intrusive remedy is available (Least Restrictive or Intrusive Remedy Principle). 
Finally, one clarification should be made explicit here. Neither ethicists nor legal theorists presume that in order to justify limiting basic rights, the individual whose rights are to be limited need be in any way culpable or morally responsible for any possible harm they may cause. Thus we allow officials to quarantine populations of people to prevent the spread of highly contagious diseases even though those to be quarantined are in no respect morally or legally responsible for their exposure to the disease. As such, the harm principle justifies limiting basic rights of those who are, in every respect, innocent of any wrong doing.

\section{Birth Control and Sexual Discrimination}

So far, we have considered requirements for the limitation of individual rights that are part of the canon of traditional ethics. Now I will consider two additional requirements that are presumed, if not explicitly stated, by both ethical and legal theorists: 1. any justifiable policy may not discriminate against individuals on irrelevant grounds (including race, sex, economic class, and so on ${ }^{23}$ and 2 . no policy can be instituted without adequate evidence of possible harm.

We have come to recognize the moral unacceptability of behavior that is the result of discriminating between individuals on the basis of group membership when such membership is irrelevant to the issue at hand. It is also apparent that one cannot offer a coherent judgment of a policy unless one is adequately informed of the probable consequences of such a policy. Although these requirements seem straightforward and uncontroversial, they are the basis for holding that no policy of coerced birth control can, at this time in history, be justified.

The history of the development of birth control technology has demonstrated an extraordinary degree of discrimination against women. Both in the research and the testing of possible birth control devices, scientists have exhibited a willingness to 
experiment upon and intervene in the reproductive processes of women rather than men. Not only is funding of research thoroughly unbalanced, with $75 \%$ of birth control research funding directed toward methods intended to control female fertility, ${ }^{24}$ but possible technologies directed toward controlling male fertility have been abandoned on the basis of mild side effects ${ }^{25}$ or simple lack of interest. ${ }^{26}$ Conversely, methods of birth control directed against female fertility have been marketed, despite knowledge of significant possible side effects and/or lack of knowledge of side effects altogether. ${ }^{27}$

There are a variety of reasons for this discrimination. As Philip Corfman, former director of the Center for Population Research at the National Institutes of Health, admitted "Most physicians are male and some males are afraid of tampering with themselves." 28 This natural bias against using one's own sex as a guinea pig for reproductive technology then becomes rationalized in a variety of ways, including claims that because a woman's reproductive physiology is more complex than a man's, it is a more promising locus of intervention. Not only is this claim illogical, it is also indefensible on biological grounds. ${ }^{29}$ Sometimes a justification is offered on the basis of supposed psychological differences. For example, Robert Kistner, in explaining why a male birth control pill had not been attempted prior to the development of a female birth control pill, maintained, "that the male is more sensitive to the psychological factors of the sex act than the female.",30 But again, there is no evidence to support this claim nor similar claims attempting to justify discrimination in birth control research and development.

An additional reason for bias in the development of birth control technology appears to be the assumption that women should be the responsible and self-controlled participants in sexual acts, whereas men, whose sexual drives are held to be much stronger, are viewed as not really capable of being responsible for or controlling their sexual behavior. On this basis it is held that men 
cannot be expected to participate in birth control. Feminist literature has dealt with this assumption in a number of contexts and has clearly demonstrated that such a view is indefensible, ${ }^{31}$ but the mythology appears to persist. In 1992 the only dependable temporary form of birth control available to men is still the condom. Owing to renewed interest in the condom because of its ability to significantly lessen the transmission of the HIV (AIDS) virus, it has been redesigned and is now being marketed as a barrier device for women (i.e., to be inserted into a woman as opposed to being put on a man). This device, the so called "female condom," has been approved for marketing despite the fact that when an FDA panel approved it, they admitted that "the ... data did not support claims that the female condom prevents the spread of sexually transmitted diseases and did not provide enough statistical basis for calculating effectiveness in preventing pregnancy. ${ }^{32}$ Clearly, a sexist bias for birth control devices to be utilized by, and applied to, women persists.

It is therefore not surprising that the only individuals currently capable of being coerced to use birth control are women. The only temporary birth control device that has been developed to interfere with the male's role in reproduction, the condom, could not be coerced without an extraordinary violation of privacy. Indeed, no technology capable of utilization in a policy of coerced birth control for men is expected within the next decade. As the evidence clearly indicates, this is not the result of some accident of nature or fate but rather of a long standing practice of discrimination in the development of birth control technology. As such, any policy of coercing birth control is de facto discriminatory at this time because birth control technology is de facto discriminatory at this time. One cannot avoid the charge of discrimination in such instances by maintaining that such policies would neither be innately nor intentionally discriminatory. Even if a policy neither explicitly nor intentionally discriminates against any particular group, it would still be discriminatory if discrimi- 
nation would, in fact, occur as a result of factors independent of the policy itself. In this instance, we are dealing with secondary discrimination, i.e., discrimination that occurs when a practice or policy depends on some other practice that is innately and/or intentionally discriminatory. Although the law is not always consistent in recognizing and rejecting secondary discrimination, ${ }^{33}$ both ethical tradition and common sense acknowledge the unacceptability of secondary discrimination. ${ }^{34}$ Whenever a practice or policy A utilizes or depends on a discriminatory practice or policy B, policy A can still be appropriately charged with discrimination. As such, no policy of coerced birth control can be considered justifiable until such a policy can be equally enforced against both men and women.

A second factor in the history of the development of birth control devices must be explicitly considered when discussing the justifiability of any such policy. Specifically, the history of birth control technology has involved an abysmal failure on the part of the medical profession and the FDA to protect women against the marketing of devices that have ultimately proven to be dangerous, and, in some instances, fatal. Even cursory familiarity with the history of birth control pills, ${ }^{35}$ IUDs, ${ }^{36}$ and Depo-Provera ${ }^{37}$ indicate an alarming lack of concern and responsibility in the development and marketing of birth control devices. As such, any policy that would coerce the use of birth control devices, either for women or men, must minimally require higher standards than those currently employed to assure the safety of such devices. Without long term careful analysis of data to insure adequate evidence of the safety of such a device, our knowledge of the true consequences of a policy coercing usage would be insufficient to support any claim that such a policy was justifiable.

The discussion above thus indicates two additional conditions required if a policy of coerced birth control is to be justified. They are: a policy of coerced birth control must be nondiscriminatory in nature; and a policy of coerced birth control must be restricted to birth control technologies established to be safe for the user. 


\section{Coerced Birth Control and Three Suggested Policies}

Having identified five conditions necessary to justify the limitation of the individual rights of privacy, reproduction, and bodily autonomy, we are now in a position to consider the three policies suggested at the outset of this chapter. Specifically, we will consider whether coercion of birth control could be justified in order to:

1. Prevent child abuse (physical assault);

2. Prevent increasing the number of children receiving welfare; or

3. Prevent those convicted of certain drug offenses from reproducing.

Clearly, given the discussion in the preceding section, no policy of coerced birth control whatsoever is currently justifiable owing to the discriminatory nature of birth control technology. Therefore, in this section we will consider the following question: If, at some future date, birth control devices were available for use by both men and women that posed no significant health risk to the user, would it be justifiable to coerce their use in any of these instances?

\section{The Prevention of Child Abuse}

On the basis of The Test of "Rational Relationship," a policy coercing the use of birth control to prevent child abuse is always unjustifiable. The individual who abuses a child does so in his/her capacity and role as custodial parent and not in his/her role as biological parent. But there are a variety of reasons why an individual might choose to biologically parent a child even though he/she may not be able to obtain parental custody of that child. Because biological and custodial parenting are separate and separable functions, such a policy would fail to meet the criterion of 
"rational relationship." Thus, although one can certainly justify limiting an individual's right to act as custodial parent in order to prevent child abuse, ${ }^{38}$ one cannot justify coercing birth control in order to do so.

In addition, the coercion of birth control is a far more intrusive and restrictive measure with regard to privacy, bodily autonomy, and reproductive rights, than is the removal of (all) custodial parenting rights. Certainly, one might hope that an individual who was denied custodial parenting rights on the basis of child abuse would elect to prevent future births. ${ }^{39}$ But it is far more intrusive and restrictive to coerce birth control (including the method of birth control) than to deny an individual custodial rights to any future children. As such, such a policy also fails the criterion of The Least Restrictive or Intrusive Remedy Principle.

\section{Prevention of Increasing the Number of Children on Welfare}

A policy offering $\$ 500$ to a woman on welfare for agreeing to have Norplant ${ }^{\circledR}$ inserted may be touted as "an inducement," but to a woman with children living on welfare, such an "inducement" must be viewed as coercive. Although technically women on welfare could "choose" not to have the implant, our understanding of "coercion" traditionally allows for other "choices" than the one being coerced. Ms. Johnson could "choose" to go to prison for an additional 3 years rather than have a Norplant ${ }^{\circledR}$ implant. Similarly I could "choose" to let you pull the trigger of the gun you are holding to my head rather than agree to rob the poor box. In all three cases, however, the "inducement" to perform the desired action is so heavily weighted on that side, that no true free choice is possible. For a woman on welfare who is raising children, a $\$ 500$ "inducement" fee could make the difference in her ability to provide adequate nutrition for her children, to obtain the child care necessary for her to receive training that could provide her with employment, or to provide necessary medical treatment for her children that 
would not be available through public assistance. This is why Ms. Julie Mertus, a lawyer with the ACLU has stated:

We would be delighted if this were part of a package to improve reproductive health care for women, and there were no monetary incentives, but it's a bribe that pushes women into one choice instead of creating more choices. When a woman receiving Aid to Families with Dependent Children is offered $\$ 500$, it crosses the line into unconstitutional coercion. ${ }^{40}$

But even if such policies are acknowledged as being coercive, we still must determine whether or not they constitute justified coercion. I will argue that such policies are not justifiable because they violate three criteria necessary for limiting rights.

First, even if the policy was to be considered only after birth control devices are made available for coercion of both sexes, without a major change of societal structures and practices, the policy would still be discriminatory, both sexually and racially. Since welfare mothers are not solely responsible for the reproduction of their children, they should not be the sole targets of such a policy. But because society and the courts discriminate against men being given (sole) custody of their children and because the welfare system strongly discriminates against giving welfare to two-parent families, women become the sole targets of such policies. In addition, because racial discrimination keeps minority women disproportionately unemployed or underemployed, such a policy would impact disproportionately on minority populations. For this reason, when a similar policy was suggested in an editorial in the Philadelphia Inquirer, "The editorial was so widely denounced by both the newspaper's staff and readers as racist that the newspaper later printed an apology.",

Even if such a policy were not racially and sexually discriminatory, it is not clear that it would satisfy the harm principle. The harm to be avoided would presumably be the harm to society of producing another child to be supported on welfare. But is this 
harm adequate to limit fundamental rights of welfare recipients? So long as government is capable of funding projects that are not absolutely necessary (and few governments are not) it is doubtful that the harm done to society is sufficient to deny welfare recipients their rights to bodily autonomy, privacy, and reproductive freedom. Such a policy also presumes a good number of questionable probabilities. Since the harm principle requires that the harm is highly probable (or, if very serious, reasonably probable) it would have to be demonstrated that someone currently on welfare is likely to remain on welfare in order to justify the policy. In addition, in order to be nonarbitrary and nondiscriminatory, it would be necessary to demonstrate that individuals currently on welfare are (far) more likely to remain on welfare than those not currently on welfare, e.g., those near the poverty level who are likely to require welfare in the future. Otherwise, the latter group, posing equal or near equal potential "harm" to the society should also, in theory, be liable to similar coercion.

Finally, such a policy appears to fail the criterion of "least restrictive remedy." Funds used to coerce birth control under such a policy could be utilized to provide (even coerced) skill or job training that could enable welfare recipients to get themselves (and their existing children) off the welfare roles. Such a measure would surely be both less restrictive and less intrusive than a policy of coerced birth control.

\section{Coerced Birth Control and Drug Offenders}

Can we justify a policy of coerced birth control as a condition of probation for individuals convicted of certain drug offenses? It would appear that two separate issues are being conflated into this one question. On the one hand, we must contend with the question of what punishment is reasonable and appropriate for those convicted of specific drug offenses? On the other hand, we are concerned with preventing birth defects that may be brought about by drug abuse. But one can be convicted of a drug offense without personally abusing drugs. Conversely, many people are guilty of drug (or other chemical) abuse that is potentially harm- 
ful to future offspring even though they have not been convicted of any drug offense. As such, there is no "rational relationship" between conviction for drug offenses and birth control. Therefore, on the whole, most policies coercing birth control as a condition of probation for drug offenses would fail The Test of "Rational Relationship." It would be far more rational and efficacious to establish a policy of coerced drug testing rather than a policy of coerced birth control in these instances. We can require that convicted drug offenders undergo mandatory drug testing as well as drug abuse rehabilitation and counseling rather than mandatory birth control as a condition of their probation. If these mandatory test results are positive for usage, the offender could and should be returned to jail. As such, the suggested policy of coerced birth control for drug offenders would violate our understanding of the justifiable limitation of the fundamental rights to privacy, bodily autonomy, and reproduction.

What shall we say of instances in which drug offenses are connected with birth defects, instances in which drug offenses involve abusing drugs that are prone to lead to birth defects? Although the abuse of some illegal drugs is known to cause serious birth defects (particularly when used prior to conception or during pregnancy), abuse of alcohol and abuse of many legal drugs are also known to cause serious birth defects. ${ }^{42}$ Therefore, on the basis of consistency, we must hold that if we decide to coerce birth control to prevent birth defects in instances involving illegal drug usage, we must adopt a policy that will apply equally to instances in which birth defects are caused by alcohol abuse or legal drug abuse. If concern about birth defects is at the heart of the suggestion that we coerce drug offenders to use birth control, then it is their chemical abuse and not their criminal offense that is the basis of this policy. As such, we need to consider a policy that would coerce birth control in order to prevent the birth of severely defective infants rather than considering a policy directed solely (and irrelevantly) at convicted drug offenders. I shall consider such a policy in the final section of this essay. 


\section{Is the Coercive Use of Birth Control Ever Justified?}

Given the discussion above, I believe that there are a rather narrow range of situations that could, in theory, justify the coercive use of birth control. Such situations would be ones in which an individual would be likely to cause serious harm to others in his/her role as biological parent and when no less intrusive or restrictive means is available for preventing the harm. Such instances would justify a policy of coerced birth control if the policy was used in a nondiscriminatory fashion (racially, sexually, and so on) and involved only those birth control devices that, based on adequate research trials, could be demonstrated to be safe for its users.

What sorts of instances would this criteria include? In what follows, I will discuss what I take to be the most obvious instance in which coerced birth control would appear to be justifiedinstances in which birth control is coerced in order to prevent the birth of severely defective children. ${ }^{43}$

\section{Preventing the Birth of Severely Defective Children}

Coerced birth control might be justified in the event that an individual or couple were very likely to produce a child with serious abnormalities or diseases, ones likely to produce a very poor quality of life for the child and its family (as well as creating a serious drain on community resources). This could occur as the result of genetic weaknesses, diseases, or chemical abuse.

Thus, if our knowledge of genetics ever reaches the point where we can predict that a particular couple has a very high probability of producing a child that is profoundly mentally or physically handicapped, we might be justified in coercing birth control. If an individual has a serious disease that significantly impacts on one's quality of life and if there is a high probability 
of the disease being transmitted to an unborn child, this might also justify coercing birth control. ${ }^{44}$ If an individual is abusing alcohol and/or drugs and we can establish a high probability of producing a child with serious abnormalities as a result of the abuse, we might also be justified in coercing birth control.

But even these instances are not straightforward. Our knowledge of genetics and physiology would have to be far more advanced than is currently the case. We would need, for instance, a consistent set of standards for determining how probable the harmful outcome would have to be in order to justify coerced birth control. As the Harm Principle indicates, the less serious the possible harm, the more probable it must be in order to justify limiting individual rights. Thus we would have to determine, with regard to each particular disease or abnormality, how probable the harm must be in order to justify limiting individual rights. If, for example, a couple had a $30 \%$ chance of producing a hydrocephalic child, would this be a sufficiently high probability to justify coercing the use of birth control? Would 80\%? 95\%? It is far from clear that we could establish such standards on any nonarbitrary basis.

We would also have to be sufficiently knowledgeable regarding genetics and diseases to determine that what appears to be a harmful anomaly or disorder is not tied to a significant beneficial quality. For example, although the sickle cell anemia trait appears to be a highly undesirable genetic quality potentially leading to the development of sickle cell anemia disease, carriers of the sickle cell anemia trait have greater protection against falciparum malaria. ${ }^{45}$ As such, it is not clear that the sickle cell anemia trait would be a satisfactory candidate for elimination from the gene pool.

In addition, adequate genetic information may ultimately suggest that virtually all humans carry genetic propensities for highly undesirable traits. Is the likelihood of producing daughters prone to develop breast cancer less harmful than the likelihood of producing a Down Syndrome child? If we determine that it is acceptable to coerce birth control in order to avoid producing children with genetic weaknesses, abnormalities, or specific dis- 
eases, with adequate knowledge, we may discover that none of us would be suitable biological parents.

What should we say in instances in which children are born with profound disabilities owing to a parent abusing alcohol or drugs? Can we, for example, justify coercing birth control for a woman who has already produced children with fetal alcohol syndrome or birth defects resulting from cocaine usage? Assume in such instances that this woman has already been provided with adequate counseling for her addiction but continues to abuse her chemical of choice. Is she a possible legitimate candidate for coerced birth control? Unfortunately, even in this instance, a remedy of coerced birth control is not unproblematic. We do not, for example, know enough about drug and alcohol abuse to know to what extent environmental factors precipitate the abuse. There is good evidence that poverty contributes significantly to drug usage. (A disproportionate percentage of drug users appear to be poor.)

In addition, it is far more likely that an individual using publicly funded agencies will be detected as fitting this criterion than one receiving services through private agencies and health professionals. Thus a disproportionately high percentage of those recognized to constitute a danger to the health of their fetuses owing to chemical abuse will be poor. As such, this suggested policy is liable to be unjustly discriminatory on the basis of economic class and concurrently (as a result of racial discrimination) race.

Finally, with regard to all of the instances above, it is not clear that the harm to be prevented is adequate to justify the potential harm to the society that such a policy may precipitate. Do we want to live in a society in which government determines who may and may not reproduce, one in which the government's decision is based on the likelihood of producing "defective" children? Or is the potential harm of producing such children not as serious as the potential harm of establishing a government with the legitimate capacity to intervene in what is traditionally recognized as a very private decision? The answer to this question largely rests on our evaluation of the number of defective chil- 
dren likely to be produced through genetic abnormalities, diseases passed through reproduction, and drug and alcohol abuse. There may come a time when these numbers are perceived to be sufficiently high to justify governmental intervention. But at this time, both our knowledge of these issues as well as the number of defective children born annually do not appear adequate to justify a policy of coerced birth control.

In addition, given that in at least two of the above instances ${ }^{46}$ no culpability rests with the potential parent, it would seem that less restrictive, less intrusive means might be equally satisfactory. Thus rather than coercing the use of birth control, the state would be more justified in offering or even coercing individuals to attend courses that would educate prospective parents on the problems connected with their biological parenting and then allow them to choose alternative methods of birth control or abortion. If such a policy were equally or nearly equally efficacious in preventing the birth of profoundly handicapped children, then on the basis of the criterion of Least Restrictive Remedy coerced birth control would still not be justifiable.

\section{Conclusion}

What then should we conclude given the discussion above? Perhaps, most obviously, that simply because technological developments make certain policies possible, this in no way speaks to their desirability. The fact that individuals within both legislative and judicial branches of government have attempted casually, simplistically, and precipitously to coerce the usage of Norplant ${ }^{\circledR}$ (within months of its initial marketing) should be a significant source of alarm to the America public. Little if any weight appears to have been given to consideration of the extent to which such policies would limit individual rights, impact on the health of those forced to use the technology, or further sexual and racial discrimination. 
In addition, we must recognize that although there may be instances in which coerced birth control could be justified, the impact of such policies on personal autonomy, the potential health risks innate to almost all methods of birth control and the danger of such policies being the basis for de facto discrimination support the view that such policies should be among the last considered to remedy any anticipated harm.

\section{Acknowledgment}

I am deeply indebted to my friends and colleagues Robert Good and Frank Anechiarico for their helpful comments on and criticisms of an earlier draft of this paper.

\section{Notes and References}

${ }^{1}$ New York Times, January 5, 1991.

${ }^{2}$ New York Times, October 19, 1991.

${ }^{3}$ American Family Physician, July, 1991, pp. 103-108.

${ }^{4} \mathrm{New}$ York Times, January 10, 1991.

${ }^{5}$ This was established in 1942 in Skinner v Oklahoma, a sterilization case in which the court maintained "this legislation involves one of the basic civil rights of man. Marriage and procreation are fundamental to the very existence and survival of the race.... There is no redemption for the individual whom the law touches. He is forever deprived of a basic liberty." Congress of the United States, Office of Technology Assessment, Infertility: Medical and Social Choices (US Government Printing Office, May, 1988), p. 220. ${ }^{6}$ Ibid.pp. 103-104.

${ }^{7}$ Although the courts have traditionally considered the right to bodily autonomy to be fundamental, there are two different types of instances in which the courts have recently ruled against the individual's right to decide what will happen in and to their body. In Webster v Missouri and in Bowers v Hardwick, the courts ruled 
against an individual's right to use their body in specific practices (i.e., with regard to abortion and homosexual acts). In addition, there have been a number of instances of late in which the court has forced a woman to undergo medical treatments and/or procedures to protect the health of her unborn child. (See "Here Come the Pregnancy Police," Glamour Magazine, August, 1990, pp. 203-205, 263-266.) Neither of these instances, however, is relevant to the issue of coerced birth control.

${ }^{8}$ Infertility: Medical and Social Choices, p. 204.

${ }^{9}$ Ibid. p. 205.

${ }^{10} \mathrm{See}$, e.g., Feinberg, Joel, Harm to Self, Vol. 3. Oxford University Press, Oxford, 1986, pp. 52-53, where he uses bodily autonomy as the basis for explaining personal autonomy and sovereignty. See Shafer, Carolyn M. and Marilyn Frey, "Rape and Respect," in Women and Values: Readings in Recent Feminist Philosophy by Pearsall, Marilyn Wadsworth Publishing Company, California, 1986 , pp. 188-196, where bodily autonomy is the basis for explaining domain and rightful power of consent and thus, why one has a right not to be raped. See Thomson, J. J. "A Defense of Abortion," in Pearsall, pp. 268-279 where bodily autonomy is part of her justification for the right to an abortion.

${ }^{11}$ In Roe v Wade, the court held:

"going back perhaps as far as Union Pacific R. R. Co. v Botsford (1891), the Court has recognized that a right of personal privacy, or a guarantee of certain areas or zones of privacy, does exist under the Constitution. ... These decisions make it clear that only personal rights that can be deemed 'fundamental' or 'implicit in the concept of ordered liberty,' ... are included in this guarantee of personal privacy. They also make it clear that the right has some extension to activities relating to marriage, ... procreation, ... contraception, ... . family relationships, ... and child rearing and education. ... The Court's decisions recognizing a right of privacy also acknowledge that some state regulation in areas protected by that right is appropriate. .. . a state may properly assert important interests in safe-guarding health, in maintaining 
medical standards, and in protecting potential life." From Mappes, Thomas A. and Jane S. Zembaty, Social Ethics: Morality and Social Policy. Fourth Edition, McGraw-Hill, New York, 1992, pp. 41-42.

${ }^{12}$ Mill, J. S. On Liberty Bobbs-Merrill, New York, 1956, Chapter 1 paragraph 9.

${ }^{13}$ For example, Feinberg considers five other grounds for limiting individual liberties; offense to others, harm to self, punishment of sin, benefit to self, and benefit to others, in "Grounds for Coercion," Social Philosophy, Prentice Hall, Englewood Cliffs, NJ, 1973, pp. $20-45$. ${ }^{14} \mathrm{~A}$ similar view is maintained by the European Convention on Human Rights. (See European Law Review, vol. 8, 1983, Dudgeon Case, p. 205.)

${ }^{15}$ Tauer, Carol A. "AIDS: Towards an Ethical Public Policy," AIDS and Ethics (Biomedical Ethics Reviews: 1988), eds. Almeder, Robert F. and James Humber, Humana Press, 1989, pp. 79-102.

${ }^{16}$ See, e.g., "Jew Ho v Williamson," Federal Reporter, 1900:103 pp. 10-27 (Northern District of California Circuit Court).

${ }^{17}$ See, e.g., Mills, Michael, Constance Wofsy, and John Mills, "The Acquired Immunodeficiency Syndrome: Infection Control and Public Health Law," New England Journal of Medicine 314 (April 3, 1986) pp. 931-936 and Steinbock, Bonnie, "Harming, Wronging, and AIDS" in AIDS and Ethics (Biomedical Ethics Reviews: 1988), eds. Almeder, Robert F. and James M. Humber, Humana Press, 1989, pp. 27-43.

${ }^{18}$ Tauer Ibid., Mills, Wofsy and Mills, Ibid.

${ }^{19}$ See Jew Ho v Williamson. See Camara v Municipal Court. US Reports 1967; 387, 523-540.

${ }^{20}$ See Jew Ho v Williamson, p. 18.

${ }^{21}$ See, e.g., Mills, Wofsy, and Mills, "The Acquired Immunodeficiency

Syndrome: Infection Control and Public Health Law," and Steinbock Bonnie, "Harming, Wronging, and AIDS."

${ }^{22}$ Federal Reporter 653, 2nd Series, "Rennie v Klein," p. 836. See also, Mills, Wofsy, and Mills, "The Acquired Immunodeficiency Syndrome: Infection Control and Public Health Law," Rock v Carney, Michigan Reports 1921;216, 280-291. (Supreme Court). 
Barmore v Robertson. Northeastern Reporter 1922; 134, 815821. (Illinois Supreme Court).

${ }^{23}$ See, e.g., Jew Ho v Williamson, p. 11.

${ }^{24}$ See Corea, Gena. The Hidden Malpractice, Harper \& Row, New York, 1985, p. 150. This figure refers to National Institute of Health funding at the time of publication. According to the Program Analysis Branch of the National Institute of Child Health and Human Development of the NIH, the proportional funding of birth control research in 1991 has significantly improved. According to an in-house analysis done on a project-by-project basis, excluding research on sterilization, of the $\$ 18,000,000$ funded by the NIH for birth control research in $1991,57 \%$ was directed toward female fertility whereas $43 \%$ was directed toward male fertility. No information on private funding of research is currently available.

${ }^{25}$ Corea, pp. 178-88. Arditti, Rita. "Have You Ever Wondered about the Male Pill?" in Seizing Our Bodies: The Politics of Women's Health. ed. by Claudia Dreifus, Random House, New York, 1977, pp. 126-127.

${ }^{26}$ Corea p. 150, 177, 179-188. Arditti, Rita, pp. 121-128.

${ }^{27}$ Corea, pp. 149-176. Vimal Balasubrahmanyan, "Women as targets in India's family planning policy," and Scarlet Pollock, "Refusing to take women seriously: 'side effects' and the politics of contraception," in Test-Tube Women: What Future for Motherhood? ed. by Rita Arditti, Renate Duelli Klein, and Shelley Minden, Pandora Press, Boston, 1984, pp. 153-164, 138-152.

${ }^{28}$ Corea, p. 178.

${ }^{29}$ Corea, pp. 177-178. Rita Arditti, Seizing Our Bodies, pp. 11-12. ${ }^{30}$ Corea, p. 178.

${ }^{31}$ See, e.g., Shafer and Frye. "Rape and Respect." See also Foa, Pamela. "What's Wrong with Rape," in Vetterling-Braggin, Mary et al. eds. Feminism and Philosophy. Littlefield, Adams \& Co., New Jersey, 1977, pp. 313-332 and Peterson, Susan Rae. "Coercion and Rape: The State As a Male Protection Racket," pp. 360-371. ${ }^{32} \mathrm{New}$ York Times National, February 1, 1992, p. 7.

${ }^{33} \mathrm{For}$ a discussion of the treatment of secondary discrimination in the law, see MacKinnon, Catherine A. Feminism Unmodified: 
Discourse s on Life and Law. Harvard University Press, Cambridge, 1987, pp. 64-65.

${ }^{34}$ If I own a contracting company and only employ carpenters belonging to union $\mathrm{X}$, a union that I know discriminates against minority workers, I cannot avoid the charge of discrimination by insisting that I personally am not discriminating. Nor can I claim that I have no moral responsibility for discrimination when I knowingly join a restricted country club. Even if I join the club simply because I wish to use their facilities (and not because I want or intend to discriminate), I am still morally culpable for supporting unjustifiable discrimination.

${ }^{35}$ Corea, pp. 151-159, 170-175. Seaman, Barbara. "The Dangers of Oral Contraception," Arditti, Seizing Our Bodies, p. 75-85.

${ }^{36}$ Corea, pp. 150, 159-165. Dowie, Mark and Tracy Johnston, "The Case of Corporate Malpractice and the Dalkon Shield," in Seizing Our Bodies, pp. 86-104.

${ }^{37}$ Corea, pp. 165-169, 175-176. Phillida Bunkle, "Calling the shots? The international politics of depo-provera," in Seizing Our Bodies, pp. 165-187.

${ }^{38}$ Indeed, I would argue that one should do so. Sadly, the courts often neglect to do so and as a result, far too many children remain under custodial control of abusive parents.

${ }^{39}$ I do not here intend to suggest that this alternative is one that does not have serious drawbacks. The plight of children who are in the custodial care of the state would be difficult in the best of circumstances; and unfortunately, given the state of foster care in the US currently, the plight of such children is very difficult indeed. I am simply maintaining that the harm caused to children who would be born under these circumstances (and placed in foster care), would not be as great as the harm done to those whose basic rights would be abrogated under a policy of coerced birth control as well as the harm done to the society as a result of adopting such a policy.

${ }^{40}$ New York Times, February 9, 1991.

${ }^{41}$ New York Times, February 9, 1991.

${ }^{42}$ Indeed, according to Beth Conover, RN MS (in genetic counseling) of the Nebraska Terategon Project, University of Nebraska Medical Center, at present, studies linking birth defects with chemical use have only established a significant risk of birth defects in the 
instance of alcohol abuse and the use of accutane, a prescription drug used to treat acne. (In fact women are coerced to use birth control as a condition of receiving a prescription for accutane.) Preliminary studies on illegal drugs indicate a moderate risk of birth defects linked to cocaine usage, but it has not yet been established to what degree this risk is connected to the concurrent abuse of alcohol. Finally, it should be noted that this is the only policy that is discussed in this paper for which men may not be targets, i.e., based on current studies, there is no clear evidence that male chemical abuse is linked to any birth defects.

${ }^{43}$ There are certainly other instances that might justify coerced birth control which I have not considered here. For example, a policy of coerced birth control might be justified in situations of serious overpopulation. Thus in countries where population significantly outreaches available food supply, the state might be justified in coercing birth control to prevent large scale harm to the society of further overpopulation. But not only would it be necessary to construct such policies so they would be nondiscriminatory in nature, it would also be necessary to determine that no less restrictive policy (e.g., education, readily available selection of birth control devices, and so on) would be equally efficacious.

${ }^{44}$ Note that this description does not appear to apply in the instance of AIDS. This is because "most infants who become infected acquire the virus [AIDS] during the birthing process." (New York Times, January 7, 1992. p. C-3.) Studies are currently underway that are testing methods to prevent the spread of the disease during the birth process. If successful, having AIDS will not impact on one's role as biological parent. In addition, "All children with HIV-infected mothers test positive at birth. In the first few years of life, however, many 'seroconvert' as their own immune systems develop, and they grow up free of the disease." (Parade Magazine, February 23, 1992) As such, we are not currently able to determine the probabilities of an HIV-infected parent producing a child with AIDS.

${ }^{45}$ See Wilson, Jean et al. ed., Harrison's Principles of Internal Medicine, 12th edition McGraw-Hill, New York, 1991.

${ }^{46}$ I would argue that in the third scenario, the instance of alcohol or drug abuse you are still often dealing with a disease and as such, no culpability should attach to the individual. 